\title{
Binary Logistic Regression Analysis of Teacher Self-Efficacy Factors Influencing Literacy and Numeracy
}

\author{
Jarrod Sio Jyh Lih", ${ }^{1, *}$ Ramlee bin Ismail ${ }^{1}$ \\ ${ }^{1}$ Faculty of Management \& Economics, Sultan Idris Education University, Tanjung Malim, Perak, Malaysia \\ *Correspondence: Faculty of Management \& Economics, Sultan Idris Education University, Malaysia. Tel: \\ 60-143-754-897. E-mail: malinkyrobot@yahoo.com
}

Received: January 19, 2019

Accepted: February 15, 2019 Online Published: February 20, 2019

doi:10.5430/wje.v9n1p209

URL: https://doi.org/10.5430/wje.v9n1p209

\begin{abstract}
This paper discusses the teacher efficacy factors contributing to student achievement in literacy and numeracy in 105 primary schools within Sibu division, Sarawak, Malaysia. The study observed high levels of practice for teacher efficacy. The t-test and one-way analysis of variance (ANOVA) were used to analyze the differences between gender, teaching experience and academic qualification. The study reported significant differences in respondent perceptions based on teaching experience. Here, the post hoc Tukey test revealed that efficaciousness grows with years of teaching experience. A correlation test observed a significant relationship between the independent variable with student achievement in literacy. Binary logistic regression was applied to predict the influence of teacher efficacy on literacy and numeracy. The findings revealed that a dimension of teacher self-efficacy - efficacy in student engagement emerged as the best predictor for student achievement for English literacy (LBI). The result indicated that for every 1-point increase in the self-reported efficacy for student engagement, the school was .014 times less likely to achieve $100 \%$ literacy rate for LBI. In conclusion, the teacher's self-efficacy in student engagement had a negative influence on the mastery of basic literacy for the English language, hence necessitating a closer inspection of the variable within the context of LINUS2.0. However, more comprehensive studies are needed to ascertain its consistency as well as investigating positive predictors for literacy.
\end{abstract}

Keywords: efficacy, binary, regression, literacy

\section{Introduction}

The Malaysian Ministry of Education (MoE) established the Literacy and Numeracy Screening (LINUS) program in Malaysia in 2010 in response to the perceived inadequacy of existing educational approaches and strategies at the time to arrest illiteracy, despite the initiation of various remedial programs (Curriculum Development Division, 2015). On the international front, similar programs include: Australia's National Assessment Program Literacy and Numeracy (NAPLAN); National Strategy to Improve Literacy and Numeracy among Children and Young People 2011- 2020 (Ireland); the Learning Support Program (LSP) and Learning Support for Maths (LSM) in Singapore; and the National Literacy and Numeracy Programmes (United Kingdom). Most of these programs involve some sort of screening once or twice annually to monitor students' progress in basic reading, writing and mathematical skills. Oftentimes, data from these screenings are used as cornerstones for school-level remedial reading and numeracy intervention programs. The same methodology is used for the LINUS2.0. Continuing where the KIA2M program left off, the LINUS program was formulated to include the Malay and English Language, as well as numeracy (Tubah \& Hamid, 2011). This program is especially pertinent to Sarawak, in view of its students' low performance in a multitude of public examinations, when ranked with the other Malaysian states (MoE, 2013, p. 3-17). This problem has impacted the country's needs for the highly-skilled, creative and innovative workforce to drive competitiveness on the 21 st-century global economic stage. Furthermore, low-achievement in literacy and numeracy will hamper efforts by the MoE to improve the country's standing in two major international large scale assessments, the Trends in International Mathematics and Science Study (TIMSS) and the Program for International Student Assessment (PISA).

Interest in teacher self-efficacy is evidenced by the number of studies that had been conducted within the country 
(Rahmah Murshidi, Mohd Majid Konting, Habibah Elias, \& Foo Say Fooi, 2006; Aziah Ismail, Loh Hooi Yen, \& Abdul Ghani Kanesan Abdullah, 2015; Teh Pei Ling, Zaidatol Akmaliah Lope Pihie, Soaib Asimirin, \& Foo Say Fooi, 2015). Most of these researchers have investigated factors of teacher efficacy within the ambits of school culture, pedagogy and school leadership. However, few studies have looked into teacher efficacy within the context of literacy and numeracy. This study scrutinizes the question: why are school children still failing to grasp the basics of literacy and numeracy by Year 3? Is it because of the teachers' own beliefs with regards to the delivery of the lesson or whether the students learn? To that end, it would be instructive to investigate how teachers' beliefs about teaching and learning (the teacher's sense of efficacy), as it might help offer an explanation for the below-average performance of primary school students in Sarawak and could be used to develop strategies for school improvement.

\section{Review of Literature}

The review of literature for this study focuses on the teacher efficacy and its link with, literacy, numeracy and student achievement, as follows:

\subsection{Teacher Efficacy}

Studies on the teacher's sense of efficacy have yielded findings that point to its influence on student achievement (Morris, Usher, \& Chen, 2016) and its role in classroom dynamics and the way classrooms function (Zee \& Kooman, 2016). Further, a plethora of meta-analyses and reviews by educational researchers have made teachers' self-efficacy or beliefs a subject of scrutiny and interest. This surge in interest is accompanied by uplifting reports and findings that valorize the importance of teachers' self-efficacy and its influence on students' behaviour and learning. The bulk of these researchers study the measurement, effects and conceptualization of teachers' self-efficacy (Klassen \& Tze 2014; Kleinsasser 2014; Wyatt, 2014; Zee \& Kooman, 2016).

In particular, a meta-analysis by Klassen and Tze (2014) found a strong correlation between teachers' self-efficacy and how their colleagues, supervisors and administrators perceive and assess their effectiveness. Equally important is the significant correlations found between teacher efficacy and students' achievement, which is an insight into how teachers' self-efficacy affects students' experiences in the classroom (Klassen \& Tze, 2014). This is consistent with studies about how teachers who report a higher sense of self and collective efficacy tend to exhibit positive behavior (Ross, 1998; Goddard, Hoy, \& Woolfolk-Hoy, 2000; Wheatley, 2002; Labone, 2004). In addition, these studies have also identified teacher efficacy as a significant predictor for teachers' commitment to teaching and competence.

Researchers have found that teachers with high levels of teacher efficacy are more willing to explore approaches and strategic ideas in the classroom. These same teachers would have students who score higher on literacy achievement tests, specifically, language arts (Goddard, Goddard, Eun \& Miller, 2015; Calik, Sezgin, Kavgaci, \& Kilinc, 2012). Teachers scoring highly on teacher efficacy were found to have students who were more interested in schooling and reported better achievement in numeracy (Duyar, Gumus, \& Bellibas, 2013).

There is a positive correlation between the rise of self- efficacy beliefs and when teachers witness improvement in student achievements due to the teaching. The raised self-efficacy leads to higher persistence and effort by the teacher. Conversely, repeated failures may result in lower self-efficacy beliefs, demotivation and decreased resilience (Morris, Usher \& Chen, 2016).

\subsection{Literacy and Numeracy in Malaysia}

The Literacy and Numeracy Screening (LINUS) program aims to ensure the mastery of the Malay Language Literacy (LBM) and Numeracy (NUM) after three years of primary schooling for students in Years 1 to 3, with the exception of students with special needs. In 2013, the Ministry of Education introduced English Language Literacy (LBI) to the list, after which it is better known by the acronym LINUS2.0. A number of studies on the LINUS program have been in recent years. An example includes Ong, Roselan, Anwardeen and Mohd Mustapa's (2015) granular examination of the quality of LBI assessment in Malaysia, in which they concluded LINUS2.0 to be an effective and sufficiently robust program, if executed according to expectations. Another study by Bokhari, Md Rashid and Chan (2016) focused on the teachers' perceptions towards the implementation of LBI at school level. While the study highlighted the obstacles they faced while running the program, most of the teachers perceived its impact on the students' performance positively. Hadzir, Alias, Kamaruzaman and Mohd Yusof (2016) used a semi-structured interview research design and focused on the program's effect on Year 1 students. Nazariyah Sani and Abdul Rahman Idris's (2012) work on Orang Asli students in Hulu Langat, and Tubah and Hamid's (2011) study were qualitative in design while Musliman, Ariffin and Din (2013) used a quantitative design, with a focus on the students' spatial intelligence and their ability to recognize alphabets and numbers. 
A slew of studies on literacy have used multivariate logistic regression (Daraganova, Edwards, \& Sipthorp, 2013; Greyling, 2015; Zubrick et al., 2015). Logistic regression analytic methods are used to isolate the causal effect of literacy and numeracy attainment. These studies observed the result of the often binary (pass/fail) nature of the dependent variable. In addition, some of the studies employed linear regression (Snowling, Hulme, Bailey, Stothard \& Lindsay, 2014; Carmichael, MacDonald \& McFarland-Piazza, 2014; Lane \& Murray, 2015) and mixed effects regression (Purpura, Hume, Sims, \& Lonigan, 2011). This paper will focus on binary logistic regression within the context of teacher efficacy.

\subsection{The Link Between Teacher Efficacy and Student Achievement}

Teachers who report high levels of teacher efficacy show would be more open to try novel or new pedagogy ideas in the classroom. Studies by Tschannen-Moran, Woolfolk-Hoy and Hoy (1998) have borne this out. Furthermore, the studies found that the students of these same teachers score higher on language arts and other literacy tests. High efficacy teachers also have students who show more interest in schooling and score better in numeracy tests. (Tracz \& Gibson, 1986; Ross \& Cousins, 1993).

A multitude of educational researchers have reported on the link between the teacher's sense of self-efficacy and student achievement (Allinder, 1995; Ashton \& Webb, 1986; Tracz \& Gibson, 1986; Ross, 1992, 1994). The researchers advanced the idea that the teacher's behavior is influenced by the level of self-efficacy, which in turn influences the student's academic performance and their behavior. This is relevant to the teaching of literacy, where the range of the students' reading levels are wide (Baumann, Hoffman, Duffy-Hester, \& Moon, 2000).

Studies have found that teachers with low self-efficacy have a higher tendency to continue with ineffective teaching, in spite of overwhelming evidence to the contrary. Further, they tend to lay the blame on students for their failure in following lessons and give up on them earlier. These teachers also have a higher tendency to refer students for special education classes or intervention (Norton, 2017; Podell \& Soodak, 1993). Conversely, a teacher with a high sense of self-efficacy would have a higher tendency to explore different instructional strategies until the students are successful in their learning (Beauchamp, Klassen, Parsons, Durksen \& Taylor, 2014).

This is particularly pertinent to literacy instruction, where the range of the students' reading levels are wide (Holzberger, Philip \& Kunter, 2014; Baumann, Hoffman, Duffy- Hester, \& Moon, 2000). In such a situation, teachers would have to make complex decisions in order to differentiate the instruction and meet the students' needs. To a certain extent, effective literacy instruction hinges upon the teacher's perceived self- efficacy that the skills needed to deliver the lesson can be performed successfully under stressful and unpredictable situations.

\section{Material and Method}

\subsection{Research Model}

The data collection method in this study is survey - a method used to make generalizations onto the population (Creswell, 2012).

\subsection{Data Collection Tools}

This study uses an adapted version of Tschannen-Moran et al's (1998) Teacher Self-Efficacy Survey (TSES). This conforms to Bryman's (2011) suggestion that it is the most efficient and reliable method of getting feedback from large research samples. Divided into 12 items and subsumed under 3 sets, The Teacher Self Efficacy Survey (TSES) uses a five-point Likert scale.

\subsection{Sample}

The sum total of schools in Sibu division is 150 (Sarawak Department of Education, 2017). The sample size suitable for this study, according to Krejcie and Morgan (1970), is $n=108$. To that end, the sample is selected using stratified sampling, with the schools chosen from a list attained from the education offices of Sibu, Selangau and Kanowit. Overall, 1183 lower primary teachers are selected as respondents.

\subsection{Socio-Demographic Information Form}

The following is the distribution of respondents based on gender, age, teaching experience, academic qualification and subject taught. 
Table 1. The Distribution of Respondents Based on Gender, Age, Teaching Experience, Academic Qualification and Subject Taught $(\mathrm{n}=694)$

\begin{tabular}{lcc}
\hline Variables & Frequency & Percent \\
\hline Gender & 168 & $24.2 \%$ \\
Male & 525 & $75.7 \%$ \\
Female & 170 & $24.2 \%$ \\
$<$ 30 years old & 307 & $44.2 \%$ \\
$30-39$ years old & 148 & $21.3 \%$ \\
$40-49$ years old & 69 & 9.9 \\
$>50$ years old & & \\
Teaching Experience & 300 & $40.7 \%$ \\
$<10$ years & 245 & $35.3 \%$ \\
$10-19$ years & 119 & $17.1 \%$ \\
$20-29$ years & 30 & $4.3 \%$ \\
$>30$ years & & \\
Academic Qualification & 65 & $8.7 \%$ \\
SPM & 61 & $8.3 \%$ \\
STPM / Diploma & 384 & $52.3 \%$ \\
Bachelor degree & 1 & $.1 \%$ \\
Master degree & & \\
Subject Taught & 225 & $30.5 \%$ \\
LBM & 209 & $28.5 \%$ \\
LBI & 260 & $35.4 \%$ \\
NUM & &
\end{tabular}

\subsection{Teacher Self-Efficacy Survey (TSES)}

Teacher efficacy is the independent variable in this study, with student achievement for literacy and numeracy the dependent variable. The independent variable is based on the framework for the teacher self-efficacy- the Teacher Self-Efficacy Model - as advanced by Tschannen-Moran, Woolfolk-Hoy, \& Hoy, (1998). Subsumed under the teacher efficacy (TE) framework are dimensions such as efficacy in classroom management, efficacy in instructional strategies and efficacy in student engagement. Using the TSES, this study looks at the extent to which the teacher is a role model to his/her students. The teacher's ability to imbue confidence in the student when resolving problems, for instance, is part of student engagement. Additionally, the ability of the teacher to gauge the student's needs and help to acquire it hews closely to the dimension of instructional strategies (Tschannen Moran, Woolfolk-Hoy \& Hoy, 1998).

Tschannen-Moran, Woolfolk Hoy and Hoy (1998) conceived and developed the Teacher Self Efficacy Survey (TSES) to measure the dimensions subsumed within the Teacher Self-Efficacy Model. Initially known as the Ohio State Teacher Efficacy Scale (OSTES), The TSES comes with two forms, referred to as the short form and the long form. The TSES aims to profile teacher perceptions of their current ability, resources and opportunity related to their own classroom behaviour, as per the descriptors. Within each form are 24 items which are intended to measure the three dimensions of teacher's sense of self-efficacy: efficacy of classroom management, the efficacy of instructional strategies and efficacy of student engagement. Each of the dimensions contains 8 items. From previous researches, the full scales have produced reliability scores that range from .92 to .95 . Reliability scores for the dimensions have ranged from .86 to .90 (Tschannen-Moran et al., 2001).

The TSES is chosen because it is a widely-used and validated assessment of the teachers' perceptions of support and satisfaction with their own professional performance. Although the original TSES scale assesses the items on a 9-point continuum, the adapted TSES 5-points Likert scale is used here, ranging from Nothing (1) to A Great Deal (5). 
Table 2. Internal Consistency Reliabilities for the TSES Short Form (Tschannen-Moran et al., 2001)

\begin{tabular}{lll}
\hline Scales of the TSES & No. of items & $\alpha$ \\
\hline Instruction & 4 & 0.86 \\
Management & 4 & 0.86 \\
Engagement & 4 & 0.81 \\
\hline
\end{tabular}

From three studies, Tschannen-Moran et al. (2001) evaluate the TSES's construct validity by scrutinizing correlations among the three subscales. These correlation scores range from .07 to .84. Tschannen-Moran et al. (2001) reported the reliability coefficients of the TSES's short form subscales to range from .81 to .86 .

The unweighted means of the items loading onto each factor is computed to determine the scores for the subscales Efficacy in Student Engagement, Efficacy in Instructional Practices and Efficacy in Classroom Management. The items are grouped as follows:

Efficacy in Student Engagement : Items 2, 3, 4, 11

Efficacy in Instructional Strategies : Items 5, 9, 10, 12

Efficacy in Classroom Management : Items 1, 6, 7, 8

\section{Results}

The levels of practice for TE is observed by way of descriptive data. To analyze the differences between gender, teaching experience and academic qualification are analyzed using the t-test and one-way analysis of variance (ANOVA). Following this, a post hoc Tukey test is used to hone in on the specific differences inherent in the dataset. Further, correlations between the independent variable and student attainment scores in literacy and numeracy is observed. The dependent variable is the school's LINUS2.0 screening results. Binary logistic regression is applied to predict the independent variables' influence on student achievement. The data for correlation and binary logistic regression were analyzed using SPSS version 24.0.

3.1 One-Way ANOVA and Post-Hoc Tukey Test

Table 3. One-Way ANOVA Comparison of Groups Based on Teaching Experience Towards Teacher Efficacy $(\mathrm{n}=694)$

\begin{tabular}{|c|c|c|c|c|c|c|}
\hline Subscales of Teacher Efficacy & Variations & SS & df & MS & $F$ & Sig \\
\hline \multirow[t]{3}{*}{ Effectiveness in Student Engagement } & Between Groups & 65.30 & 3 & 21.77 & & \\
\hline & Within Groups & 1101.02 & 689 & 1.60 & 13.62 & .00 \\
\hline & Total & 1166.312 & 692 & & & \\
\hline \multirow[t]{3}{*}{ Effectiveness in Instructional Strategies } & Between Groups & 131.01 & 3 & 43.70 & & \\
\hline & Within Groups & 1641.54 & 689 & 2.38 & 18.34 & .00 \\
\hline & Total & 1772.64 & 693 & & & \\
\hline \multirow[t]{3}{*}{ Effectiveness in Classroom Management } & Between Groups & 30.50 & 3 & 10.17 & & \\
\hline & Within Groups & 2089.29 & 688 & 3.03 & 3.35 & .02 \\
\hline & Total & 2119.79 & 692 & & & \\
\hline
\end{tabular}

Clues: $\quad 1:<10$ Years, 2: 10-19 Years, 3: 20-29 Years, 4: $>30$ Years

SS - Sums of Squares, df - Degrees of Freedom, MS - Mean Square

As shown in Table 3, there is the significant statistical difference in mean score for Effectiveness in Student Engagement, where the $F(3,689)=13.62, p=.00$ Meanwhile, the Effectiveness in Instructional Strategies aspect shows the statistically significant difference between mean scores at $F(3,689)=18.34, p=.00$ based on the teachers' years of teaching experience. Similarly, the Effectiveness in Classroom Management aspect shows the statistically significant difference between mean scores at $F(3,689)=3.35, p=.02$. 
Table 4. Summarized Tukey Test Result for Teacher Efficacy Subscales Based on Teaching Experience ( $\mathrm{n}=694)$

\begin{tabular}{|c|c|c|c|c|}
\hline \multirow[t]{2}{*}{ Subscales of Teacher Efficacy } & \multicolumn{4}{|c|}{ Mean Difference } \\
\hline & (I)Exp2 & $(\mathrm{J}) \operatorname{Exp} 2$ & $(\mathrm{I}-\mathrm{J})$ & Sig \\
\hline \multirow[t]{12}{*}{ Effectiveness in Student Engagement } & $<10$ Years & 10-19 Years & -.24 & .12 \\
\hline & & 20-29 Years & -.76 & 00 \\
\hline & & $>30$ Years & -.96 & 00 \\
\hline & 10-19 Years & $<10$ Years & .24 & .12 \\
\hline & & 20-29 Years & -.52 & .00 \\
\hline & & > 30 Years & -.72 & .02 \\
\hline & 20-29 Years & $<10$ Years & .76 & .00 \\
\hline & & 10-19 Years & .52 & .00 \\
\hline & & $>30$ Years & -.20 & .87 \\
\hline & $>30$ Years & $<10$ Years & .96 & .00 \\
\hline & & 10-19 Years & .72 & .02 \\
\hline & & 20-29 Years & .20 & .87 \\
\hline \multirow[t]{12}{*}{ Effectiveness in Instructional Strategies } & $<10$ Years & 10-19 Years & -.52 & .00 \\
\hline & & 20-29 Years & -1.18 & .02 \\
\hline & & $>30$ Years & -.93 & .01 \\
\hline & 10-19 Years & $<10$ Years & .52 & .00 \\
\hline & & 20-29 Years & -.66 & .00 \\
\hline & & $>30$ Years & -.41 & .52 \\
\hline & 20-29 Years & $<10$ Years & 1.18 & .00 \\
\hline & & 10-19 Years & .66 & .00 \\
\hline & & $>30$ Years & -.25 & .86 \\
\hline & $>30$ Years & $<10$ Years & .93 & .01 \\
\hline & & 10-19 Years & .41 & .52 \\
\hline & & 20-29 Years & -.25 & .86 \\
\hline \multirow[t]{12}{*}{ Effectiveness in Classroom Management } & $<10$ Years & 10-19 Years & -.16 & .72 \\
\hline & & 20-29 Years & -.50 & .04 \\
\hline & & $>30$ Years & -.71 & .14 \\
\hline & 10-19 Years & $<10$ Years & .16 & .72 \\
\hline & & 20-29 Years & -.34 & .29 \\
\hline & & $>30$ Years & -.56 & .35 \\
\hline & 20-29 Years & $<10$ Years & .50 & .04 \\
\hline & & 10-19 Years & .34 & .29 \\
\hline & & $>30$ Years & -.21 & .93 \\
\hline & $>30$ Years & $<10$ Years & .71 & .14 \\
\hline & & 10-19 Years & .56 & .35 \\
\hline & & 20-29 Years & .21 & .93 \\
\hline
\end{tabular}

On the whole, there is a statistically significant difference between teachers who have taught for fewer than 10 years, 10-19 years, 20-29 years and more than 30 years, $F(3,689)=14.99, p=.00$. Tables 4.22 (a) summarize the means scores and post hoc Tukey test for the aspects of teacher efficacy. A post hoc Tukey test shows that the biggest mean differences are between $>30$ years and $<10$ years for effectiveness in student engagement (.96), effectiveness in instructional strategies (.93) and effectiveness in classroom management (.71).

\subsection{Correlation}

To determine the strength of relationship between the variables, the researcher uses the estimates of strength as 
recommended by Davis (1971). The correlation, $\mathrm{r}$ value and strength of the relationships between variables are summarized in Table 3.

Table 5. The Strength of Relationship between Variable

\begin{tabular}{lll}
\hline Correlation Analysis & $\mathrm{r}$ & Strength of Relationship \\
\hline Relationship between TE and & LBM $(\mathrm{r}--.190, \mathrm{p}-.052) ;$ & $\begin{array}{l}\text { A strong, significant, but negative } \\
\text { correlation between TE and student } \\
\text { Student achievement in literacy }\end{array}$ \\
LBI $(\mathrm{r}=-.188, \mathrm{P}=.054)$ & $\begin{array}{l}\text { achievement in LBM and LBI. No } \\
\text { significant correlation between TE and } \\
\text { student achievement in NUM. }\end{array}$ \\
\hline
\end{tabular}

Table 5 shows the following correlational result: LBM $(r=-.190, p=.052)$; LBI $(r=-.118, p=.054)$ and NUM $(r$ $=.046, p=.645)$. The table shows that there is no significant correlation between teacher efficacy and student achievement in literacy and numeracy in the primary schools studied.

\subsection{Binary Logistic Regression}

Binary logistic regression in SPSS 24.0 was used to determine the influence of predictor variables on student achievement. In assessing the influence of teacher efficacy on literacy and numeracy, the independent variable student engagement - made a statistically significant contribution to the model. Recording an odds ratio of .49 for NUM, this indicated that for every additional unit increase in teacher efficacy score for student engagement, respondents were .49 times less likely to achieve the national KPI for NUM.

Direct logistic regression was performed to assess the impact of a number of factors on the likelihood of teacher efficacy subscales influencing student achievement in LBM. The model contained three independent variables (student engagement, instructional strategies and classroom management). The full model containing all predictors was statistically significant, $\chi^{2}(3, \mathrm{~N}=105)=10.028$, with a $p$ value of .018 , indicating that the model was able to distinguish between subscales that influence and did not influence student achievement in LBM.

The model as a whole explained between 9.1\% (Cox and Snell R squared) and 12.5\% (Nagelkerke R squared) of the variance in teacher efficacy, and correctly classified $67.6 \%$ of cases. As shown in Table 4, one of the independent variables made a unique statistically significant contribution to the model. However, teacher efficacy for student engagement in LBM recorded an odds ratio of .014, which was less than 1 . This indicated the school is over 71 times more likely to experience a literacy rate of $100 \%$ in LBM without student engagement, controlling for other factors in the model. The results for binary logistic regression is summarized in Table 6.

Table 6. Logistic Regression Predicting Likelihood of Teacher Efficacy Subscales Influencing LBM

\begin{tabular}{llllllllc}
\hline & \multicolumn{1}{c}{} & & & & & 95\% C.I. for Odds Ratio \\
\hline Variables & $\mathrm{B}$ & S.E. & Wald & df $\mathrm{p}$ & & Exp(B) & Lower & Upper \\
\hline Student Engagement & -4.106 & 1.464 & 7.866 & 1.005 & & .016 & .001 & .290 \\
Instructional Strategies & 1.329 & 1.662 & .639 & 1.424 & 3 & .777 & .145 & 98.122 \\
Classroom Management & .585 & 1.215 & .232 & 1.630 & 1 & .796 & .166 & 19.436 \\
Constant & 8.575 & 4.553 & 3.547 & 1.060 & 5 & 298.851 & & \\
\hline
\end{tabular}

To examine the impact of a number of factors on the likelihood of teacher efficacy subscales influencing student achievement in English literacy (LBI), the model considers 3 independent variables (student engagement, instructional strategies and classroom management). The logistic regression presented the full model containing all predictors as statistically significant, $\chi^{2}(3, \mathrm{~N}=105)=10.586$, with a p-value of .014 , indicating that the model was able to distinguish between subscales that influence and did not influence student achievement in LBI. As a whole, the model explained between 9.6\% (Cox and Snell R squared) and 12.9\% (Nagelkerke R squared) of the variance in teacher efficacy, and correctly classified $68.6 \%$ of cases.

Table 7 shows that one of the independent variables made a unique statistically significant contribution to the model. Here, teacher efficacy for student engagement in LBI recorded an odds ratio of .016, which, at less than 1, indicated the school is over 62 times more likely to experience a literacy rate of $100 \%$ in LBI without student engagement, controlling for other factors in the model. 
Table 7. Logistic Regression Predicting Likelihood of Teacher Efficacy Subscales Influencing LBI

\begin{tabular}{|c|c|c|c|c|c|c|c|c|}
\hline \multicolumn{9}{|c|}{ 95\% C.I. for Odds Ratio } \\
\hline Variables & $\mathrm{B}$ & S.E. & Wald & df $p$ & & $\operatorname{Exp}(\mathrm{B})$ & Lower & Upper \\
\hline Student Engagement & -4.106 & 1.464 & 7.866 & 1.005 & & .016 & .001 & .290 \\
\hline Instructional Strategies & 1.329 & 1.662 & .639 & 1.424 & 3 & .777 & .145 & 98.122 \\
\hline Classroom Management & .585 & 1.215 & .232 & 1.630 & 1 & .796 & .166 & 19.436 \\
\hline Constant & 8.575 & 4.553 & 3.547 & 1.060 & 5 & 298.851 & & \\
\hline
\end{tabular}

In assessing the impact of a number of factors on the likelihood of teacher efficacy subscales influencing student achievement in NUM, a logistic regression model is produced. Containing 3 independent variables (student engagement, instructional strategies and classroom management). The full model containing was not statistically significant, $\chi^{2}(3, \mathrm{~N}=105)=2.807$, with a $p$ value of .422 , which suggested that the model was unable to distinguish between subscales that influence and did not influence student achievement in NUM. Overall, the model as explained between 2.7\% (Cox and Snell R squared) and 3.8\% (Nagelkerke R squared) of the variance in teacher efficacy, with $72.1 \%$ of the cases classified correctly. Table 8 shows that none of the independent variables made a unique statistically significant contribution to the model.

Table 8. Logistic Regression Predicting Likelihood of Teacher Efficacy Subscales Influencing NUM

\begin{tabular}{llllllll}
\hline & & & & & & \multicolumn{3}{c}{ 95\% C.I. for Odds Ratio } \\
\hline Variables & $\mathrm{B}$ & S.E. & Wald & df $\mathrm{p}$ & $\operatorname{Exp}(\mathrm{B})$ & Lower & Upper \\
\hline Student Engagement & -1.991 & 1.455 & 1.874 & 1.171 & .137 & .008 & 2.362 \\
Instructional Strategies & 2.755 & 1.803 & 2.335 & 1.126 & 15.724 & .459 & 538.490 \\
Classroom Management & -.576 & 1.307 & .194 & 1.659 & .562 & .043 & 7.281 \\
Constant & .295 & 4.776 & .004 & 1.951 & 1.343 & & \\
\hline
\end{tabular}

\section{Discussion and Conclusion}

The first key finding of this study is related to teacher self-efficacy. The biggest mean differences were between the responses of those on both extremes of teaching experience: those who have had 30 years of experience and those who have had fewer than 10 years' experience. This finding supports Fives and Buehl's (2010), findings that teachers with more than 10 years of experience (especially at primary school level) gained greater teaching efficacy than those who were just starting out in teaching. Broadly, findings from Mohd Khairuddin Abdullah \& Halimah Laji's (2015) and Soodak and Podel's (1996) studies suggest that with more experience, teachers grow in efficaciousness and confidence in their teaching. This pattern is consistent for all three dimensions of teacher efficacy, as evidenced from the post-hoc Tukey test result outlined in the previous chapter. Other researchers are in agreement with this data (Christenson, Reschly, \& Wylie, 2012; Dixon, Yssel, McConnell, \& Hardin, 2014; Skinner, Pitzer, \& Steele, 2016).

On that note, Zepeda (2016) provided a possible explanation for this phenomenon, by linking teacher efficacy with supervision and evaluation (another strong predictor for student achievement that will be explained later in this chapter). Novice teachers can benefit from a supportive structure in order to make a smoother entrance into what would be a life-long career. These beginning teachers' beliefs or self-efficacy would be shaped in the initial years of their profession - the experiences which would guide them throughout their teaching years. Veteran teachers, with their years of experience, can establish a mentorship grounded on the sharing of the best instructional methodology. The headmaster as the de facto instructional leader can aid this by recognizing that teachers at any part of career timeline can do with some assistance - be it from a credible and qualified veteran or the administrators themselves.

The teaching can always be improved. With appropriate supervision and evaluation on teachers by the headmaster, schools can develop teachers professionally, increase their confidence in teaching and in turn, improve student achievement (Zepeda, 2017). On a related note, Lumpe, Czerniak, Haney and Beltyukova (2012) found that teachers who participated in intense teacher development programs reported gains in their teaching self-efficacy beliefs. Teachers with more years of teaching experience under their belts could have enjoyed more professional development contact hours which contribute to their own high sense of teaching self-efficacy. Overall, effectiveness in student engagement, effectiveness in instructional strategies and effectiveness in classroom management- all 
recorded high levels of self-efficacy. This indicates that teachers in primary schools reported high levels of self-efficacy. This is supported by data from Kuching and Samarahan (Teng, 2006) and in congruence with researches on teacher self-efficacy done elsewhere in Malaysia by Khalid (2009), Ebmeier (2003) and Demir (2008).

The second key finding of this study is the statistical significance of the variable student engagement, a subscale of the variable teacher efficacy for LBM and LBI. Here, the result of logistic regression suggested that the practice of teacher efficacy in student engagement was 71 times less likely to achieve $100 \%$ literacy rate for LBM and 62.5 times less likely to achieve $100 \%$ literacy rate for LBI. In other words, teacher efficacy in student engagement was found to have a negative relationship with LBM and LBI. The finding of the present study is congruent with those from several related studies (Moalosi, 2012; Weiss \& Garcia, 2014; Rodriguez, Regueiro, Blas, Valle, Pineiro, \& Cerezo, 2014, Lee, 2014). Weiss and Garcia's (2014) study in Mexico concluded that improvement of student achievement is not contingent upon stronger engagement, while entertaining the possibility of a negative correlation with academic outcome.

The same study reported that engagement with teachers did not translate into improved assessment scores. In fact, students who reported a higher feeling of connectedness with teachers scored lower in tests. By way of explanation, Weiss and Garcia (2014) questioned the cross- cultural applicability of the dimensions of engagement, especially on the operationalization of constructs. They suggested taking into account the teachers' qualifications, like level of education and years of experience with the current subject). On a related note, Rodriguez, Regueiro, Blas, Valle, Pineiro, \& Cerezo (2014) observed how students of overconfident teachers with a high perception of self-efficacy seemed to be less engaged compared to students of teachers with a moderate perception of self-efficacy, who demonstrated relatively lower work avoidance and less anxiety. This ties in with Lee's (2014) study among 3268 American students, where she cautioned of the small effects found in researches vaunting student engagement.

Future researches can include variables like family background and the individual when interpreting positive student engagement-academic outcome researches (Lee, 2014). Many studies have reported of other relevant factors influencing student engagement and academic achievement (Skinner \& Pitzer, 2012; Wang \& Eccles, 2013). Perhaps more can be explained by investigating the joint effects of factors like parental educational involvement, educational aspirations and the environmental factor of schools are considered. Further research is warranted to ascertain reasons that could contribute towards this finding.

However, many researchers have also reported contrarian views in the body of literature vis-à-vis student engagement and teacher efficacy (Reyes, Bracket, Rivers, White, \& Salovey, 2012; Christenson, Reschly, \& Wylie, 2012; Reeve, 2013; Upadyaya \& Salmela-Aro, 2013). It also runs counter to previous studies, where teachers were found to be most efficacious in relation to classroom management and least efficacious with activities related to student engagement (Fives \& Buehl, 2010).

This finding is shows that not all the subjects were influenced by the same predictor variables. Using this finding as a guide, school heads can place a sizeable emphasis on establishing a community of practice, with experienced teachers as mentors or teacher leaders. These teachers are more confident and more willing to go above and beyond routine classroom duties, as per the finding of this study. Future research can be conducted to investigate how efficaciousness can be imbued and inculcated amongst younger in-service teachers who are just starting out in their career.

\section{References}

Allinder, R. M. (1995). An Examination of the Relationship between Teacher Efficacy and Curriculum-Based Measurement and Student Achievement. Remedial and Special Education, 16(4), 247-254. https://doi.org/10.1177/074193259501600408

Ashton, P. T., \& Webb, R. B. (1986). Making a difference: Teachers' sense of efficacy and student achievement. New York: Longman.

Aziah Ismail, Loh Hooi Yen \& Abdul Ghani Kanesan Abdullah. (2015). Professional Learning Community and Self Efficacy of teachers in Penang Secondary Schools. Journal of Educational Leadership, 2(1). Universiti Kebangsaan Malaysia.

Beauchamp, L., Klassen, R., Parsons, J., Durksen, T., \& Taylor, L. (2014). Exploring the development of teacher efficacy through professional learning experiences. Report prepared for the Alberta Teachers' Association: NW.

Bokhari, R., Md Rashid, S., \& Chan, S. H. (2016). Teachers' Perception on the Implementation of the Literacy, 
Numeracy and Screening (LINUS LBI 2.0) Programme among Lower Primary ESL Pupils. Malaysian Journal of ELT Research, 11(11), 108-121.

Calik, T., Sezgin, F., Kavgaci, H., \& Kilinc, A. C. (2012). Examination of relationsips between instructional leadership of school principals and self-efficacy of teachers and collective teacher efficacy. Educational Sciences: Theory \& Practice, 12(4), 2498-2504.

Carmichael, C., MacDonald, A., \& McFarland-Piazza, L. (2014). Predictors of numeracy performance in national testing programs: insights from the longitudinal study of Australian children. British Educational Research Journal, 40(4), 637-659. https://doi.org/10.1002/berj.3104

Christenson, S. L., Reschly, A. L., \& Wylie, C. A. (2012). The Handbook of Research on Student Engagement. New York, NY.: Springer Science. https://doi.org/10.1007/978-1-4614-2018-7

Creswell, J. W. (2012). Educational Research, Planning, Conducting, and Evaluating Quantitative and Qualitative Research. Boston, MA: Pearson.

Daraganova, G., \& Sipthorp, M. (2011). The Longitudinal Study of Australian Children: Wave 4 weights (LSAC Technical Paper No. 9). Melbourne: Australian Institute of Family Studies.

Demir, K. (2008). Transformational leadership and collective efficacy: the moderating roles of collaborative culture and teacher' self-efficacy. Egitim Arastirmalari-Eurasian Journal of Educational Research, 33, 93-112.

Dixon, F. A., Yssel, N., McConnell, J. M., \& Hardin, T. (2014). Differentiated Instruction, Professional Development, and Teacher Efficacy. Journal for the Education of the Gifted, 37(2), 111-127. https://doi.org/10.1177/0162353214529042

Duyar, I., Gumus, S., \& Bellibas, M. S. (2013). Multilevel analysis of teacher work attitudes: the influence of principal leadership and teacher collaboration. International Journal of Educational Management, 27(7), 700-719. https://doi.org/10.1108/IJEM-09-2012-0107

Ebmeir, H. (2003). How supervision influences teacher efficacy and commitment: an investigation of a path model. Journal of Curriculum and Supervision, 18(2), 110-141.

Fives, H., \& Buehl, M. M. (2010). Examining the Factor Structure of the Teachers' Sense of Efficacy Scale. The Journal of Experimental Education, 78, 118-134. https://doi.org/10.1080/00220970903224461

Goddard, R. G., Hoy, W. K., \& Woolfolk Hoy, A. (2000). Collective teacher efficacy: Its meaning, measure, and impact on student achievement. American Educational Research Journal, 37, 479-508. https://doi.org/10.3102/00028312037002479

Goddard, R., Goddard, Y., Eun, S. K., \& Miller, R. (2015). A theoretical and empirical analysis of the roles of instructional leadership, teacher collaboration and collective efficacy beliefs in support of student learning. American Journal of Education, 121(4), 501-530. https://doi.org/10.1086/681925

Hadzir, N., Alias, A. M., Kamaruzaman, A. L., \& Mohd Yusof, H. M. (2016). Teachers' perception on literacy, numeracy and screening (LINUS2.0) assessment features based on year 1 students' performance. Research Journal of English Language and Literature (RJELAL), 4(1), 2321-3108.

Holzberger, D., Philipp, A., \& Kunter, M. (2014). Predicting teachers' instructional behaviors: the interplay between self-efficacy and intrinsic needs. Contemporary Educational Psychology, 39(2), 100-111. https://doi.org/10.1016/j.cedpsych.2014.02.001

Khalid Johari. (2009). Perkembangan Efikasi Guru Sekolah Menengah Di Sabah. Jurnal Kemanusiaan, 20, 34-45.

Klassen, R. M., \& Tze, V. M. (2014). Teachers' self-efficacy, personality, and teaching effectiveness: a metaanalysis. Educational Research Review, 12, 59-76. https://doi.org/10.1016/j.edurev.2014.06.001

Kleinsasser, R. C. (2014). Teacher efficacy in teaching and teacher education. Teaching and Teacher Education, 44, 168-179. https://doi.org/10.1016/j.tate.2014.07.007.

Krejcie, R. V., \& Morgan, D. W. (1970). Determining Sample Size for Research Activities. Educational and Psychological Measurement, 30, 607-610. https://doi.org/10.1177/001316447003000308

Labone, E. (2004). Teacher efficacy: maturing the construct through research in alternative paradigms. Teaching and Teacher Education, 20, 341-359. https://doi.org/10.1016/j.tate.2004.02.013

Lane, J., \& Murray S. (2015). Smarten up: It's time to build essential skills. Report prepared for the Canada West 
Foundation.

Lee, J. S. (2014). The relationship between student engagement and academic performance: is it a myth or reality? The Journal of Educational Research, 107, 177-185. https://doi.org/10.1080/00220671.2013.807491

Lumpe, A., Czerniak, C., Haney, J., \& Beltyukova, S. (2012). Beliefs about teaching science: The relationship between elementary teachers' participation in professional development and student achievement. International Journal of Science Education, 34(2), 153-166. https://doi.org/10.1080/09500693.2010.551222

Ministry of Education. (2012). Malaysian Education Blueprint 2013-2015.: A preliminary report. Retrieved 15 October 2016 from http://www.moe.gov.my/userfiles/file/PPP/Preliminary- Blueprint-BM.pdf

Moalosi, W. T. S. (2012). Teacher Efficacy: Is Student Engagement Essential in Botswana Junior Secondary Schools? International Journal of Scientific Research in Education, 5(3), 207-213.

Mohd Khairuddin Abdullah \& Halimah Laji. (2015). A comparison of the teaching efficacy among primary one Malay language teachers. Malay Language Education Journal, 5(1), 10-17.

Morris, D. B., Usher, E. L., \& Chen, J. A. (2016). Reconceptualizing the sources of teaching self-efficacy: A critical review of emerging literature. Educational Psychology Review, 29(4), $795-833$. https://doi.org/10.1007/s10648-016-9378-y

Musliman, R., Ariffin, S. R., \& Din, R. (2013). Assessing students' spatial intelligence for literacy and numeracy skills. Procedia - Social and Behavioral Sciences, 90, 695-701. https://doi.org/10.1016/j.sbspro.2013.07.142

Nazariyah Sani. (2014). Narrowing the literacy gap of indigenous students: what are the challenges? Jurnal Personalia Pelajar, 17, 19-30.

Norton, S. J. (2017). Primary Mathematics Trainee Teacher Confidence and its Relationship to Mathematical Knowledge. Australian Journal of Teacher Education, 42(2), article 4. http://dx.doi.org/10.14221/ajte.2017v42n2.4

Ong, L. E., Roselan, F. I., Anwardee, N. H., \& Mustapa, F. H. M. (2015). Suitability of the literacy and numeracy screening (LINUS) 2.0 programme in assessing children's early literacy. The Malaysian Online Journal of Educational Science, 3(2), 36-44.

Purpura, D. J., Hume, L. E., \& Sims, D. M. (2011). Early literacy and early numeracy: The value of including early literacy skills in the prediction of numeracy development. Journal of Experimental Child Psychology, 110, 647-658. https://doi.org/10.1016/j.jecp.2011.07.004

Rahmah Murshidi, Mohd Majid Konting, Habibah Elias \& Foo Say Fooi. (2006). Sense of Efficacy Among Beginning Teachers in Sarawak. Teaching Education, 17(3), 265-275. https://doi.org/10.1080/10476210600849730

Reeve, J. (2013). How students create motivationally supportive learning environments for themselves: The concept of agentic engagement. Journal of Educational Psychology, 105, 579-595. http://dx.doi.org/10 .1037/a0032690

Reyes, M. R., Brackett, M. A., Rivers, S. E., White, M., \& Salovey, P. (2012). Classroom emotional climate, student engagement, and academic achievement. Journal of Educational Psychology, 104(3), 700-712. http://dx.doi.org/10.1037/a0027268

Rodriguez, S., Regueiro, B., Blas, R., Valle, A., Pineiro, I., \& Cerezo, R. (2014). Teacher self- efficacy and its relationship with students' affective and motivational variables in higher education. European Journal of Education and Psychology, 7(2), 107-120. https://doi.org/10.30552/ejep.v7i2.106

Ross, J. A. (1992). Teacher Efficacy and the Effects of Coaching on Student Achievement. Canadian Journal of Education / Revue canadienne de l'éducation, 17(1), 51-65. https://doi.org/10.2307/1495395

Ross, J. A. (1998). The antecedents and consequences of teacher efficacy. In J.Brophy (Ed.), Advances in research on teaching, Volume 7: Expectations in the classroom (pp. 49-74). Greenwich, CT: JAI Press, Inc.

Ross, J. A., \& Cousins, J. B. (1994). Intentions to seek and give help and behaviour in cooperative learning groups. Contemporary Educational Psychology, 19, 476-482. https://doi.org/10.1006/ceps.1994.1034

Skinner, E. A., \& Pitzer, J. R. (2012). Developmental dynamics of student engagement, coping, and everyday resilience. In S. L. Christenson, A. L. Reschly \& C. Wylie (Eds.), Handbook of research on student engagement (pp. 21-45). New York, NY: Springer Science. https://doi.org/10.1007/978-1-4614-2018-7_2 
Skinner, E. A., Pitzer, J. R., \& Steele, J. S. (2016). Can student engagement serve as a motivational resource for academic coping, persistence, and learning during late elementary and early middle school? Developmental Psychology, 52(12), 2099-2117. http://dx.doi.org/10.1037/dev0000232

Snowling, M. J., Hulme, C., Bailey, A. M., Stothard, S. E., \& Lindsay, G. (2014). Better communication research programme: Langugae and literacy attainment of pupils during early years and through KS2: does teacher assessment at five provide a valid measure of children's current and future educational attainments? Report prepared for City of York Local Authority, Centre for Reading and Language, University of York.

Soodak, L. C., \& Podell, D. M. (1996). Teacher efficacy: Toward the understanding of a multi-faceted construct. Teaching and Teacher Education, 12(4), 401-411. https://doi.org/10.1016/0742-051X(95)00047-N

Teh Pei Ling, Zaidatol Akmaliah Lope Pihie, Soaib Asimirin \& Foo Say Fooi. (2015). The validity and reliability of teacher efficacy revisited in Malaysia secondary schools. Journal of Studies in Education, 5(1), 27-35. https://doi.org/10.5296/jse.v5i1.6802

Teng, L. K. (2006). The influence of selected factors towards teacher self efficacy. In Sarawak secondary schools. Unpublished doctoral thesis. Fakulti Pendidikan. Universiti Putra Malaysia, Malaysia.

Tracz, S. M., \& Gibson, S. (1986). Effects of efficacy on academic achievement. Paper presented at the meeting of the California Educational Research Association, Marinadel Rey, CA.

Tschannen-Moran, M., Woolfolk Hoy, A., \& Hoy, W. K. (1998). Teacher efficacy: Its meaning and measure. Review of Educational Research, 68, 202-248. https://doi.org/10.3102/00346543068002202

Tubah, H., \& Hamid, Z. (2011). The Influence of Demography on Reading and Comprehension Skills of LINUS Pupils. Malay Journal, 6, 29-47.

Upadyaya, K., \& Salmela-Aro, K. (2013). Development of school engagement in association with academic success and well-being in varying social contexts. European Psychologist, 18, 136-147. http://dx.doi.org/10.1027/1016-9040/a000143

Wang, M. T., \& Eccles, J. S. (2013). School context, achievement motivation, and academic engagement: A longitudinal study of school engagement using a multidimensional perspective. Learning and Instruction, 28, 12-23. https://doi.org/10.1016/j.learninstruc.2013.04.002

Weiss, C. C., \& Garcia, E. (2014). Student engagement and academic performance in Mexico: Evidence and puzzles from PISA. Comparative education review, 59(2), 305-331. https://doi.org/10.1086/680170

Wheatley, K. F. (2002). The potential benefits of teacher efficacy doubts for educational reform. Teaching and Teacher Education, 18, 5-22. https://doi.org/10.1016/S0742-051X(01)00047-6

Wyatt, M. (2014). Towards a re-conceptualization of teachers' self-efficacy beliefs: tackling enduring problems with the quantitative research and moving on. International Journal of Research and Method in Education, 37(2), 166-189. https://doi.org/10.1080/1743727X.2012.742050

Zee, M., \& Kooman, H. M. Y. (2016). Teacher self-efficacy and its effects on classroom processes, student academic adjustments, and teacher well-being: a synthesis of 40 years of research. Review of Educational Research, 86(4), 981-1015. https://doi.org/10.3102/0034654315626801

Zepeda, S. J. (2017). Instructional supervision: Applying tools and concepts. Routledge: New York.

Zubrick S. R., Taylor C. L, \& Christensen, D. (2015). Patterns and Predictors of Language and Literacy Abilities 4-10 Years in the Longitudinal Study of Australian Children. PLoS ONE, 10(9), e0135612. https://doi.org/10.1371/journal.pone.0135612 